\title{
Occurrence of Natural Enemies of Tetranychus macfarlanei on Okra at Vidarbha Region
}

\author{
Archana N. Borkar ${ }^{*}$, A. V. Kolhe, D. B. Undirwade, H. R. Sawai and V. J. Tambe \\ Post Graduate Institute, Department of Entomology, Dr. Panjabrao Deshmukh Krushi \\ Vidyapeeth, Akola, Maharashtra, India \\ *Corresponding author
}

\section{A B S T R A C T}

Keywords

Tetranychus macfarlanei, Predatory fauna, Vidarbha, Okra

Article Info

Accepted:

24 December 2020 Available Online: 10 January 2021
An experiment was carried out during Kharif, 2017 and 2018, at three different locations of Vidarbha region to get more information on the occurrence of bioagents to control red spider mite species, Tetranychus macfarlanei on okra crop at Vidarbha region. Number of general and specific predators were found in association with the T. macfarlane $i$ in okra agro system. Predatory mite, Amblyseius sp. and predatory insect viz., Scolothrip rhagebianus, Feltiella sp., Oligata sp. and Stethorus sp. and grub of chrysopids were occurs abundantly. Predatory fauna showed significantly positive correlation with $T$. macfarlanei.

\section{Introduction}

Red spider mite, Tetranychus sp. (Tetranychidae: Arachnida) represent one of the most important group of phytophagous mites. Large population of this pest, causes heavy losses in yield. Farmers are using number of chemical pesticides on crops to fight the mite menace. But indiscriminate use of these pesticides has resulted in to the mite outbreak in many agro-ecosystems. Representatives of each major insecticide class viz., organochlorines, organophosphates, carbamates, etc. have been implicated in spider mite outbreaks. Researchers has attributed resurgence in spider mite to the detrimental effect of pesticides on their natural enemies; increased fecundity in mites; changes in mite dispersal and feeding behavior (Huffaker, et al., 1969; van de Vrie et al., 1972, Singh et al., 2014).

The high reproductive potential; short life cycle and arrhenotokous reproduction, combined with the frequent acaricide applications, facilitates rapid resistance buildup in spider mite (Chiasson, et al., 2004; Van Leeuwen, et al., 2005). In India, resistance was observed in spider mite against dicofol, abamectin, phosalone, phosphamidon, 
dimethoate, and wettable sulphur in different vegetables (Kumar et al., 2002; Shridhar and Jhansi, 2007). Development of resistance to acaricides in spider mites is often so rapid that, effective spider mite management is difficult in many agricultural systems (Jeppson et al., 1975).

So, there is a need to look farward for other options to control this pest and natural enemies or predators can be a better option. In order to practically apply these natural enemies in mite control, initially one needs to study these predators which are present in association with the spider mite.

Predatory mites, as Amblyseius longispinosus, Phytoseius minutes, Phytoseiulus persimilis, Amlyseius alstoniae and many insect predators, as Feltiella sp., Stethorus pauperculus, Scolothrips rhagebianus, Scolothrips sexmaculatus, Oligota oviformis and unidentified Anthocorid and Mirid bug, Coccinella septempunctata has been reported predaceous on the various species of spider mites (Moutia, 1958; Rachana et al., 2009; Sarma, 2010; Siddhapara, 2015; Singh and Chauhan, 2016; Naga et al., 2017).

Unlike the conventional chemical pesticides pest control by means of bioagents is eco friendly; there is no chance of resistance, and resurgence development in spider mites for bioagents. In view of all these positive side, a study was carried out to explore the natural enemies of spider mite in okra agroacosystem, and to know their abundance in okra cropecosystem in relation to biotic and abiotic factors.

\section{Materials and Methods}

A study on predatory fauna of okra red spider mite, T. macfarlanei was undertaken at three different agro-climatic zones of Vidarbha region viz., Akola (Plateau assured rainfall),
Gadchiroli (Eastern vidarbha high rainfall) and Nagpur (Central vidarbha moderate rainfall) during Kharif, 2017 and 2018.

All the recommended agronomical practices were followed in raising the okra crop (variety Arka Anamika), except plant protection. Weekly observations were taken on predatory fauna of red spider mite at Akola while, same observations was made at fortnight interval during different phenological stages of okra crop at Gadchiroli and Nagpur.

Ten plants were randomly selected from $10 \mathrm{x}$ $10 \mathrm{~m}$ plot and three leaves from basal, middle and top canopy of each plant were observed for predatory fauna of red spider mite. Predatory fauna as well as spider mite population was counted on ventral surface of leaf on $2.5 \mathrm{~cm}^{2}$ leaf area with the help of foldable magnifier hand lens $(10 \mathrm{x})$. The influence of key meteorological parameters on the predatory fauna was worked out through simple correlation studies (Gomez and Gomez, 1984). Multiple regression equations were also developed.

\section{Results and Discussion}

\section{Seasonal incidence of predatory fauna}

A good number of natural enemies of red spider mite were observed during present study. Predatory mite, Amblyseius sp. and predatory insect viz., Scolothrip rhagebianus, Feltiella sp., Oligata sp. and Stethorus sp. and grub of unknown chrysopids were occurs abundantly (Plate.1).

Present finding on predatory fauna of Tetranychus macfarlanei is in close confirmation with previous workers as: Moutia (1958) who reported Stethorus sp., Oligota sp. and Feltiella sp. as predators feeding on $T$. macfarlanei in Mauritius. 
Prasanna (2007) who reported predatory mites, Amblyseius longispinosus and Phytoseius minutes; insect predators, Oligota sp., Scolothrips rhagebianus and unidentified Anthocorid and Mirid bug feeding on tetranychus mites. Rachana et al., (2009) found Stethorus pauperculus, Amblyseius longispinosus and Phytoseiulus persimilis dominant among other predators, feeds on tetranychus mite.

For the both year, the initiation and peak population of predatory fauna was synchronized with that of spider mite, indicated prey predator association. At Akola during, Kharif, 2017 and 2018, incidence of predatory fauna was initiated during $32^{\text {nd }}$ MW. Peak population of predatory fauna was observed on $36^{\text {th }}$ MW with 2.0 predators/ plant. (Fig.1). During Kharif 2018, peak predatory fauna was recorded during $38^{\text {th }} \mathrm{MW}$ (Sept. 17-23) with 8.9 predatory fauna/ plant. Among the predators, Feltiella sp. and Oligata sp. were found dominantly (Fig 1).

At Gadchiroli during Kharif 2017 and 2018, predatory fauna appeared during $34^{\text {th }} \mathrm{MW}$ and reached to its peak during $42^{\text {nd }} \mathrm{MW}$ with 1.4 predatory fauna/ plant during 2017 and 2.7 predator/ plant during 2018 (Fig.2).

At Nagpur during Kharif 2017 and 2018, the predatory fauna was initiated during $32^{\text {nd }} \mathrm{MW}$ and reached to its peak on $42^{\text {nd }}$ MW during 2017, while during Kharif 2018, highest population of predatory fauna was observed during $38^{\text {th }}$ MW (Sept. 17-23) with 2.7 predators/ plant (Fig.3).

Present finding on predatory fauna of Tetranychus macfarlanei is in close confirmation with previous workers as: Siddhapara (2015) reported predatory beetle, Stethorus sp. and predatory mite viz., phytoseiid mite and Amblysius sp. feeding on T. urticae during 2013-14. Naga et al., (2017) who observed that, predatory mite, Amlyseius alstoniae and Coccinella septempunctata appeared in the second week of August (33 ${ }^{\text {rd }}$ MW) and second week of October ( $41^{\text {st }}$ MW) respectively and reached to peak in the third week of September $\left(38^{\text {th }}\right.$ MW) during season.

\section{Correlation and regression studies}

At Akola, during Kharif 2017 and 2018, data showed a non-significant correlation of predatory fauna with maximum temperature, minimum temperature, morning relative humidity, evening relative humidity and rainfall but, a significantly positive correlation of predatory fauna with red spider mite (" $\mathrm{r} "=0.96)$. Linear regression drawn for Kharif 2017 and 2018 showed 93\% variability in predatory fauna due to the spider mite. Data indicated that, with increase in 1 spider mite/ $2.5 \mathrm{~cm}^{2}$ predatory fauna increases in a tune of 0.13 predators/plant.

At Gadchiroli, data showed positive and significant correlation of predatory fauna with spider mite $(\mathrm{r}=0.96)$ and maximum temperature $(r=0.82)$ while, a non-significant negative correlation with minimum temperature $(\mathrm{r}=-0.43)$.

A significant but negative correlation was observed between predatory fauna and morning relative humidity $(\mathrm{r}=-0.94)$, even relative humidity $(\mathrm{r}=-0.82)$, and rainfall $(\mathrm{r}=\mathrm{-}$ 0.62 ). From the linear regression equations drawn for Kharif, 2017 and 2018, it could be inferred that, with increase of 1 unit of spider mite and maximum temperature there was proportionate increase of 0.11 and 0.32 per cent predatory population. Nevertheless for an increase in morning, evening relative humidity and rainfall by one unit there was a decrease in predatory fauna population 0.11 , 0.10 and 0.02 per cent respectively. 
Table.1 Correlation and regression studies of predatory fauna in relation with red spider mite and weather parameters at Gadchiroli

\begin{tabular}{|c|c|c|c|c|c|c|}
\hline Year & Factors & r value & t value & $\mathbf{R}^{2}$ & Linear equation & Multiple equation \\
\hline \multirow{6}{*}{2017} & Red spider mite & $0.99 * *$ & 14.43 & 0.98 & $\mathrm{Y}=0.07+0.09 *$ mite & \multirow{6}{*}{$\begin{array}{l}\mathrm{Y}=1.65+0.11 * \text { mite }-0.02 * \mathrm{RHmorn} \\
+0.01 * \text { Rainfall } \\
\left(\mathrm{R}^{2}=0.99\right)\end{array}$} \\
\hline & Temp. (Max) & 0.41 & 0.91 & ---- & --- & \\
\hline & Temp (Min) & -0.46 & -1.03 & ---- & --- & \\
\hline & RH (Morn.) & $-0.90 * *$ & -4.24 & 0.82 & $Y=13.73-0.14 *$ RHmorn. & \\
\hline & RH (Even.) & -0.57 & -1.38 & --- & --- & \\
\hline & Rainfall (mm) & $-0.93 * *$ & -5.07 & 0.87 & $Y=1.37-0.02 *$ Rainfall & \\
\hline \multirow{6}{*}{2018} & Red spider mite & $0.97 * *$ & 8.62 & 0.95 & $\mathrm{Y}=0.01+0.12 *$ mite & \multirow{6}{*}{$\begin{array}{l}Y=-72.82+0.01 * \text { mite }+1.47 * \operatorname{Tmax} \\
-0.46 * \mathrm{RHmorn}+0.86 * \mathrm{RHeven}-0.15 * \text { Rainfall } \\
\left(\mathrm{R}^{2}=1\right)\end{array}$} \\
\hline & Temp. (Max) & $0.89 *$ & 3.89 & 0.79 & $\mathrm{Y}=-10.07+0.35^{*} \mathrm{Tmax}$ & \\
\hline & Temp (Min) & -0.60 & -1.51 & --- & --- & \\
\hline & RH (Morn.) & $-0.97 * *$ & -8.36 & 0.95 & $\mathrm{Y}=10.91-0.11 * \mathrm{RHmorn}$ & \\
\hline & RH (Even.) & $-0.92 * *$ & -4.81 & 0.85 & $Y=9.15-0.10 *$ RHeven. & \\
\hline & Rainfall (mm) & $-0.84^{*}$ & -3.09 & 0.71 & $Y=1.87-0.11 *$ Rainfall & \\
\hline \multirow{6}{*}{ Pooled } & Red spider mite & $0.96^{* *}$ & 11.30 & 0.93 & $\mathrm{Y}=0.01+0.11 *$ mite & \multirow{6}{*}{$\begin{array}{l}\mathrm{Y}=6.76+0.08 * \text { mite }-0.05 * \text { Tmax- } \\
0.07 * \mathrm{RHmorn}+0.01 * \mathrm{RHeven}+0.004 * \text { Rainfall } \\
\left(\mathrm{R}^{2}=0.97\right)\end{array}$} \\
\hline & Temp. (Max) & $0.82 * *$ & 4.51 & 0.67 & $Y=-9.16+0.32 * T \max$ & \\
\hline & Temp (Min) & -0.43 & -1.53 & --- & --- & \\
\hline & RH (Morn.) & $-0.94 * *$ & -8.50 & 0.88 & $\mathrm{Y}=10.29-0.11 * \mathrm{RHmorn}$ & \\
\hline & RH (Even.) & $-0.82 * *$ & -4.58 & 0.68 & $Y=8.83-0.10 *$ RHeven. & \\
\hline & Rainfall (mm) & $-0.62 *$ & -2.47 & 0.38 & $Y=1.28-0.02 *$ Rainfall & \\
\hline
\end{tabular}


Table.2 Correlation and regression study of predatory fauna in relation with red spider mite and weather parameters at Nagpur

\begin{tabular}{|c|c|c|c|c|c|c|}
\hline Year & Factors & r value & t value & $\mathbf{R}^{2}$ & Linear equation & Multiple equation \\
\hline \multirow[t]{6}{*}{2017} & $\begin{array}{l}\text { Red spider } \\
\text { mite }\end{array}$ & $0.98 * *$ & 10.62 & 0.97 & $Y=-0.06+0.18 *$ mite & \multirow{6}{*}{$\begin{array}{l}Y=18.82-0.27 * \text { mite }+0.01 * \mathrm{Tmax} \\
-0.78 * \text { Tmin }-0.01 * \mathrm{RHeven}-0.001 * \text { Rainfall } \\
\left(\mathrm{R}^{2}=0.99\right)\end{array}$} \\
\hline & Temp. (Max) & $0.82 *$ & 2.87 & 0.67 & $\mathrm{Y}=-6.75+0.22 * \mathrm{Tmax}$ & \\
\hline & Temp (Min) & $-0.99 * *$ & -13.48 & 0.98 & $Y=8.41-0.36 *$ Tmin & \\
\hline & RH (Morn.) & -0.55 & -1.32 & --- & --- & \\
\hline & RH (Even.) & $-0.89 *$ & -3.91 & 0.79 & $Y=2.92-0.04 *$ RHeven. & \\
\hline & Rainfall (mm) & $-0.85^{*}$ & -3.20 & 0.72 & $Y=0.68-0.01 *$ Rainfall & \\
\hline \multirow[t]{6}{*}{2018} & $\begin{array}{l}\text { Red spider } \\
\text { mite }\end{array}$ & $0.98 * *$ & 9.79 & 0.96 & $\mathrm{Y}=0.03+0.18 *$ mite & \multirow{6}{*}{$\begin{array}{l}\mathrm{Y}=-7.58+0.17 * \text { mite }-0.02 * \mathrm{Tmax} \\
+0.36 * \mathrm{Tmin}+0.01 * \text { Rainfall } \\
\left(\mathrm{R}^{2}=0.98\right)\end{array}$} \\
\hline & Temp. (Max) & $0.86^{*}$ & 3.33 & 0.74 & $\mathrm{Y}=-11.11+0.39 * \mathrm{Tmax}$ & \\
\hline & Temp (Min) & $0.93 * *$ & 5.11 & 0.87 & $Y=-19.04+0.91 *$ Tmin & \\
\hline & RH (Morn.) & -0.78 & -2.51 & --- & --- & \\
\hline & RH (Even.) & -0.70 & -1.97 & --- & --- & \\
\hline & Rainfall (mm) & $-0.84 *$ & -3.06 & 0.70 & $Y=2.34-0.03 *$ Rainfall & \\
\hline \multirow[t]{6}{*}{ Pooled } & $\begin{array}{l}\text { Red spider } \\
\text { mite }\end{array}$ & $0.99 * *$ & 18.34 & 0.97 & $\mathrm{Y}=-0.047+0.19 *$ mite & \multirow{6}{*}{$\begin{array}{l}\mathrm{Y}=-2.98+0.19 * \text { mite }+0.06 * \mathrm{Tmax} \\
+0.01 * \mathrm{RH} \text { morn }+0.002 * \text { Rainfall } \\
\left(\mathrm{R}^{2}=0.98\right)\end{array}$} \\
\hline & Temp. (Max) & $0.65^{*}$ & 2.70 & 0.42 & $\mathrm{Y}=-10.04+0.34 * \mathrm{Tmax}$ & \\
\hline & Temp (Min) & 0.49 & 1.77 & --- & --- & \\
\hline & RH (Morn.) & $-0.69 *$ & -3.00 & 0.47 & $\mathrm{Y}=10.64-0.12 * \mathrm{RHmorn}$. & \\
\hline & RH (Even.) & -0.55 & -2.07 & --- & --- & \\
\hline & Rainfall (mm) & $-0.70 *$ & -3.10 & 0.49 & $Y=1.66-0.02 *$ Rainfall & \\
\hline
\end{tabular}


Fig.1 Seasonal incidence of predatory fauna in relation with biotic and abiotic factors during Kharif 2017 and 2018 at Akola

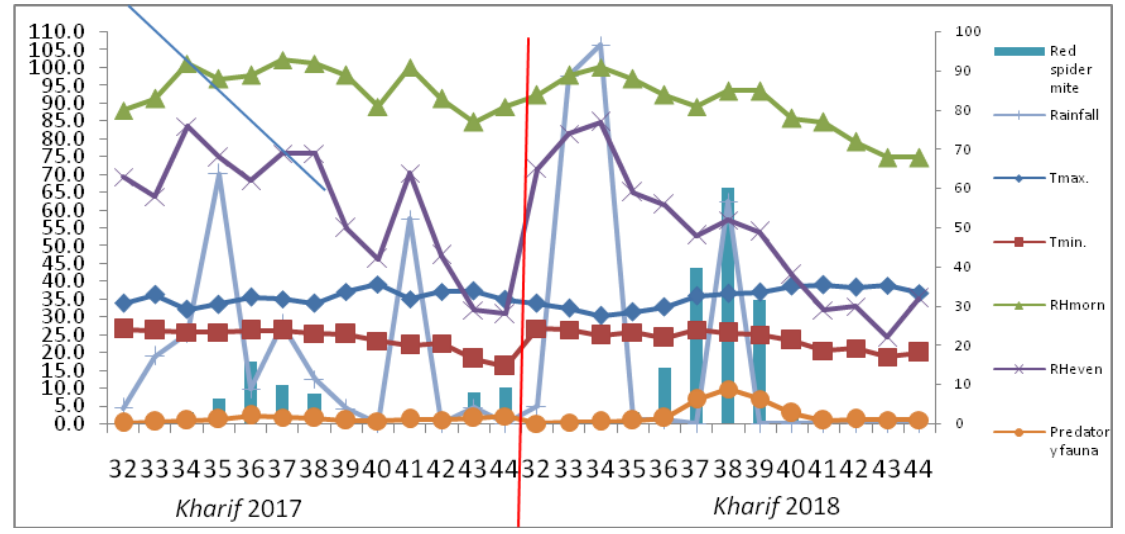

Fig.2 Seasonal incidence of predatory fauna in relation with biotic and abiotic factors during Kharif 2017 and 2018 at Gadchiroli

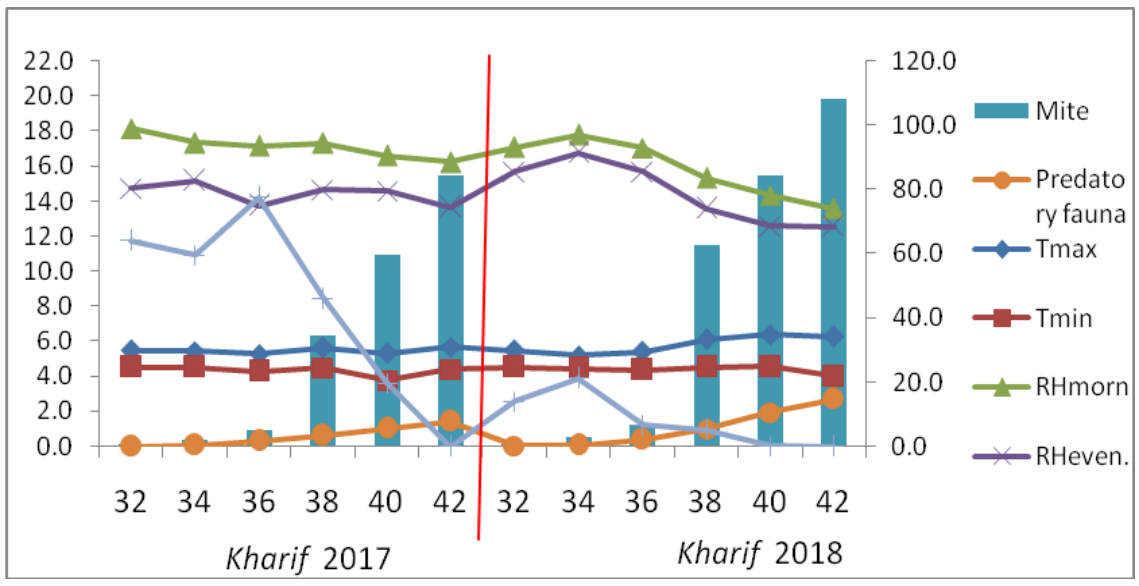

Fig.3 Seasonal incidence of predatory fauna in relation with biotic and abiotic factors during Kharif 2017 and 2018 at Nagpur

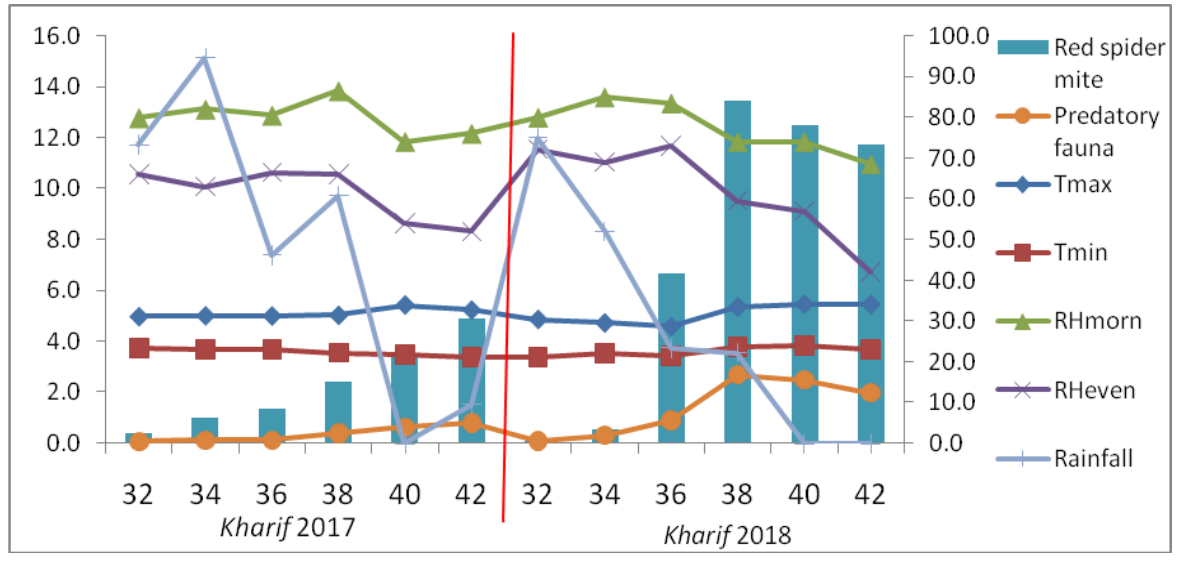


Plate.1 Predatory faunal diversity in okra crop on Tetranychud macfarlanei
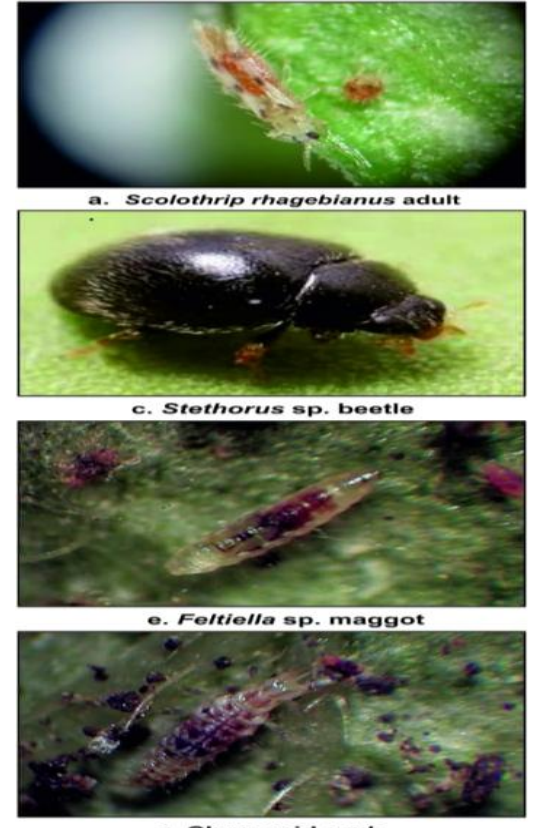

g. Chrysopid grub
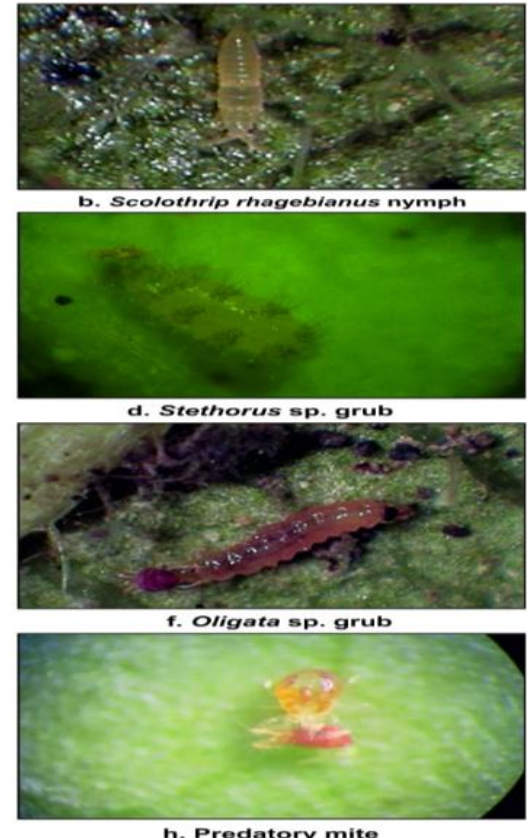

h. Predatory mite
Regression equation showed 93, 67, 88, 68, and 38 per cent of fluctuation in predatory faunal population contributed individually by spider mite, maximum temperature, morning relative humidity, evening relative humidity and rainfall respectively. During Kharif, 2017 and 2018, from multiple regressing equations, it can be concluded that meteorological factors together contributed 97 per cent variability in predatory population (Table 1).

At Nagpur during Kharif, 2017 and 2018, predatory fauna showed significant and positive correlation with spider mite $(\mathrm{r}=$ $0.99)$, maximum temperature $(\mathrm{r}=0.65)$, minimum temperature (0.49) while, a significant but negative correlation with morning relative humidity $(r=-0.69)$, and rainfall $(r=-0.70)$. From the linear regression equation drawn for Kharif, 2017 and 2018, it could be put forward that, an increase of 1 unit in spider mite and maximum temperature resulted in increase of 0.19 and 0.34 predator/ plant and contributed 97 and $42 \%$ respectively in predatory fauna variability. Increase in one unit of morning relative humidity and rainfall adversely affected predatory fauna with fall of 0.12 and 0.02 per cent and contributed 47 and $49 \%$ variability in predatory fauna respectively. Multiple regression equation revealed that the red spider mite, maximum temperature, morning relative humidity and rainfall together contributed $98 \%$ variability in predatory fauna (Table 2).

These findings are in line with the following workers as: Siddhapara (2015) showed highly significant and positive association of mite population with Stethorus sp. $\left(\mathrm{r}=0.92^{* *}\right.$ and $\left.0.95^{* *}\right)$ and predatory mites $\left(\mathrm{r}=0.92^{* *}\right.$ and $0.94 * *)$, respectively during Kharif 2013 and 2014. Jadhav, et al., (2016) reported highly significant positive association of mite population with Stethorus sp. and predatory mites during Kharif 2013 and 2014 in okra ecosystem. Singh and Chauhan (2016) reported that, the population of T. ludeni and $S$. sexmaculatus was positively correlated with temperature whereas negative correlation with relative humidity. 
Prassanna (2007); Sekhar et al., (2008); Chinniah et al., (2009); Monica et al., (2014); Siddhapara (2015); Jadhav, et al., (2016); Naga et al., (2017); Singh et al., (2018) have documented the significant positive correlation between mite population and maximum temperature, whereas a negative correlation with morning, evening relative humidity; and rainfall. Contrary to this Mandal et al., (2006) at Pusa, Bihar during summer, 2000 and 2001 reported that the, $T$. telarius in okra showed non-significant negative correlation with the maximum temperature $(\mathrm{r}=-0.52$ and -0.13$)$ during 2000 and 2001, respectively. They also found a significant positive association of mite with relative humidity while, a non-significant positive correlation of rainfall with the population of mites during both the years. Regression analysis explained 78-85 per cent variability due to meteorological parameters in T. telarius.

Chinniah et al., (2009) inferred from regression equation data that, the increase in temperature by $1{ }^{\circ} \mathrm{C}$ resulted into proportionate increase in mite population by 1.18 per cent; one unit increase in relative humidity resulted into decrease in mite population by 0.22 per cent; for every $1 \mathrm{~mm}$ increase in rainfall mite population decline by 0.19 per cent. Whereas, minimum temperature and wind velocity showed nonsignificant impact on spider mite in brinjal ecosystem.

Monica et al., (2014) worked out multiple linear regressions by taking mite population as dependent variable (Y) and climatic factors as independent variables (x). Data revealed that, the coefficient of determination $\left(\mathrm{R}^{2}\right)$ was significantly high $(73.50 \%)$.

In conclusion during the present study one predatory mite and five predatory insects were recorded to be predaceous on
Tetranychus macfarlanei in okra. Among these predators predatory thrip was identified at species level as Scolothrip rhagebianus. Data on seasonal incidence suggest that in Vidarbha region predatory fauna start to appear during $32^{\text {nd }}$ MW which gradually reach to the peak during $36^{\text {th }}, 38^{\text {th }}$ and $42^{\text {nd }}$ MW during the crop season. There is a synchronisation between peak population of spider mite and predatory fauna which suggest close prey predatory association between them. Data showed 93-97\% variability in predatory population due to the biotic and abiotic factors.

\section{Acknowledgement}

Authors are thankful to Dr. Kaomud Tyagi, Scientist, Molecular Systematics Division, Zoological Survey of India for providing species level identification of predatory thrip.

\section{References}

Chiasson $\mathrm{H}$, Bostanian NJ, Vincent C. Acaricidal properties of a chenopodiumbased botanicals. J. Econ. Entomol. 2004; 97: 1373-1377.

Chinniah C, Kumar SV, Muthiah C and Rajavel DS. Population dynamics of two spotted spider mite, Tetranychus urticae Koch in brinjal ecosystem. Karnataka Journal of Agriculture Science. 2009; 22(3): 734735.

Gomez KA and Gomez AA. Statistical procedures for agricultural research (2nd edition) John Wiley and Sons, New York. 1984; p.680.

Huffaker CB, Van De Vrie M, McMurtry JA. Ecology of tetranychid mites and their natural enemies: Annu. Rev. Entomol.1969; 14:125-174.

Jadhav, YT, Mane SR, Shinde DS. Seasonal incidence, correlation and regression among weather parameters against mites on summer okra. Internat. J. Plant Protec. 2016; 9 (2): 494-497. 
Jeppson LR, Keiffer HH, Baker EW. Mites injurious to economic plants. University of California Press, 1975.

Kumar S, Prasad S, Singh RN. Resurgence of two spotted mite, Tetranychus urticae Koch. (Acarina: Tetranycidae) due to acaricides and botanicals on okra. Ann. Plant Protec. Sci. 2002. 10 (2): 239-242.

Mandal SK, Sattar A, Banerjee S. Impact of meteorological parameters on population build up of red spider mite in okra, Abelmoschus esculentus L. under North Bihar condition. Journal of Agricultural Physics. 2006; 6(1): 35-38.

Monica VL, Kumar A, Chand H, Paswan S Kumar S. Population dynamics of Tetranychus urticae Koch on brinjal crop under north Bihar conditions. Pest Management in Horticultural Ecosystems. 2014; 20 (1): 47-49.

Moutia LA. Contribution to the study of some phytophagous acarina and their predators in Mauritius. Bulletin of Entomological Research, 1958; 49:59-75.

Naga BL, Sharma A, Khinchi SK and Kumawat KC. Seasonal incidence of mite, Tetranychus cinnabarinus (Boisduval) and natural enemies on okra in semi arid Rajasthan. Journal of Pharmacognosy and Phytochemistry. 2017; 6(3): 186-189.

Prasanna KP. Seasonal incidence and management of Tetranychid mites in brinjal. M. Sc. (Agri.) Thesis (Unpublished). University of Agricultural Sciences, Dharwad, Karnataka, 2007.

Rachana RR, Manjunatha M, Gayathridevi S, and Naik MI. Seasonal incidence of red spider mite Tetranychus neocaledonicus Andre and its natural enemies. Karnataka Journal of Agricultural Science. 2009; 21(1): 213-214.

Sarma SRA. Seasonal incidence and management of brinjal mite, Tetranychus spp. Ph. D. Thesis (unpublished). University of Agricultural Sciences, Dharwad, Karnataka (India), 2010.

Sekhar DC, Reddy DJ, Rahman SJ, Reddy AR,
Narendranath VV. Ecology and management of red spider mite, Tetranychus urticae Koch on grape. Acta Horticulturae. 2008; 785: 335-342.

Siddhapara MR. Biology, seasonal incidence and management of red spider mite, Tetranychus urticae Koch in okra. Ph. D. Thesis (Unpublished) Junagadh Agricultural University, Gujarat, 2015.

Singh AK, Koul K, Shankar U, Singh SK, Mondal A, Singh, M. Seasonal incidence and management of red spider mite, Tetranychus urticae Koch on Okra, Abelmoschus esculentus (L.) Moench. Journal of Entomology and Zoology Studies. 2018; 6 (2): 650-656.

Singh SK, Singh AP, Singh RN. Comparative bio efficacy of bio pesticides and new molecules of acaricides in the management of Tetranychus urticae Koch (Acari: Tetranychidae) in Okra. The Ecoscan. 2014; 6: 279-283.

Singh V and Chauhan U. Seasonal incidence of spider mite Tetranychus ludeni Zacher (Tetranychidae: Acari) and its predator Scolothrips sexmaculatus Pergande (Thysanoptera: Insecta) on carnation (var. Master) from Himachal Pradesh, India Journal of Biological Control, 2016; 30(4): 248-251.

Sridhar V and Jhansi RB. Resistance in twospotted spider mite, Tetranychus urticae Koch on rose from different polyhouses to dicofol and wettable sulphur. J. Acarol. 2007; 17: 48-50.

Van de Vries, M, McMurty JA, Huffaker CB. Ecology of tetranychid mites and their natural enemies: II review Ill. Biology, ecology and pest status and host-plant relations of tetranychids. Hilgdia. 1972; 41: 343-432.

Van Leeuwen T, Dermauw W, Van de Veire M, Tirry L. Systemic use of spinosad to control the two spotted spider mite (Acari: Tetranychidae) on tomatoes grown in Rockwool, Exptl. Appl. Acarol. 2005; 37: 93-105. 


\section{How to cite this article:}

Archana N. Borkar, A. V. Kolhe, D. B. Undirwade, H. R. Sawai and Tambe, V. J. 2021. Occurrence of Natural Enemies of Tetranychus macfarlanei on Okra at Vidarbha Region. Int.J.Curr.Microbiol.App.Sci. 10(01): 3644-3653.

doi: https://doi.org/10.20546/ijcmas.2021.1001.430 